\title{
MIR659 wt Allele
}

National Cancer Institute

\section{Source}

National Cancer Institute. MIR659 wt Allele. NCI Thesaurus. Code C82210.

The human MIR659 wild-type allele is located in the vicinity of 22q13.1 and is approximately 96 bases in length. This allele, which encodes MIR659 pre-miRNA, plays a role in the regulation of gene expression. Alteration in the expression of this gene is associated with developement of frontotemporal dementia. 